\title{
The Rights and Duties of Foreign Person in an Arbitration Procedure in the Russian Federation
}

\author{
${ }^{* 1}$ Damir Kh. Valeev, ${ }^{2}$ Marat R. Zagidullin, Ruslan ${ }^{3}$ B. Sitdikov, ${ }^{4}$ Yaroslav N. Larionov \\ 1, 23,4 Kazan Federal University, Faculty of Law \\ Email: larionov.rf@gmail.com
}

Received: 21st October 2017 Accepted: 16th November 2017, Published: 31st December 2017

\begin{abstract}
This paper considers the rights and obligations of foreign persons in arbitration courts of the Russian Federation. General scientific and special methods of cognition of legal reality were used. The paper addresses these aspects in relation to business entities that are parties to arbitration procedural relations. It also reveals the notions of legal standing and the existing regime of granting rights to foreign elements in an arbitration proceeding. First, the general rights and duties of these persons are described, and further attention is focused on certain provisions, such as the language of the proceedings and the procedure for providing an interpreter, reimbursement of court costs and payment of state fees, representation and protection of the interests of foreigners.

The authors describe the existing situation of foreigners in arbitration proceedings and point to the need for continuous improvement of legislation with a view to mutual integration of the economic spheres of foreign states and protection of the rights of foreign entities in the arbitration proceeding.
\end{abstract}

Keywords: Arbitration Procedure, Foreign Persons

\section{Introduction}

In the Russian Federation, foreign citizens, stateless persons, international and foreign organizations that carry out entrepreneurial and other economic activities, have the right to apply to arbitration courts of the Russian Federation for the protection of their violated rights and interests protected by law. These persons bear procedural duties and are entitled to equal procedural rights with Russian citizens and organizations. This principle is called "national treatment" [1].

State and departmental arbitration courts that existed before 1992, considered disputes between organizations belonging to the socialist camp, and they did not belong to the institutions that carry out justice. Arbitration courts of the Russian Federation deal with disputes arising from entrepreneurial and other economic activities that may also be carried out by foreign persons. Modern arbitration courts act as an organ of justice. On this count, Russian arbitration courts are identical with foreign ones, for example, French and English commercial courts or specialized offices for commercial matters in the general courts of England and Germany.
Foreign business entities may appear in court not only as complainant parties and respondent parties, but also be as third parties who declare and do not claim independent claims for a dispute, and also participate in insolvency cases and in establishing facts of legal significance, use the services of representatives. This follows from the extension of the national regime to foreign economic entities [2].

A separate chapter in the Arbitration Procedural Code of the Russian Federation is devoted to the peculiarities of dealing with cases involving foreign persons. At the same time, the Arbitration Procedural Code of the Russian Federation includes not so many articles consolidating such features; mainly they are contained in the Conventions, bilateral and multilateral treaties of the Russian Federation [3].

The trial of cases involving foreign persons in arbitration courts is conducted mainly in accordance with the national procedural legislation. If the rules of legal proceedings established by national legislation are contrary to the rules provided for by international treaties, agreements, the latter apply. Therefore, there is a need to analyze the rules of legal proceedings and, firstly, the peculiarities of the legal regulation of dealing with foreign elements in terms of national legislation, secondly, the application and, in general, the implementation of provisions of international and foreign procedural legislation.

\section{Materials and Methods}

Scientific research is carried out on the basis of scientific methods of cognition. General scientific methods of research were used (including structured system and dialectical methods).

Along with this, special methods of cognition of legal reality were applied: comparative legal, historical and legal, formally legal, etc. In some cases, the system approach was used in the present work, the method of interpretation of law and legal modeling were also used.

The theoretical basis for the study was the development of Russian pre-revolutionary, Soviet and modern time periods in the general theory of law, the theory of civil and arbitration procedural law, and the international civil proceedings experience. The subjects of attention were also main principles of international civil and arbitration proceedings. The achievements of the Russian legal science were used in the work. The normative base of the research was made up of regional, universal and bilateral international treaties 
concluded on behalf of the Russian Federation or the treaties of the USSR operating in the Russian Federation by way of succession, the norms of the Russian law, and, within certain limits, of foreign law. In the course of the work, materials of judicial and arbitration practice were widely used, first of all, judicial decisions in which it comes to the interpretation and application of international treaties [5].

\section{Results and Discussion}

The legal capacity of an individual or an entity concerned is realized by applying to the arbitration court. From this moment the origin of arbitration procedural legal relations begins. The procedural legal capacity is defined as the ability to have procedural rights and bear procedural obligations. All citizens and organizations equally possess the procedural legal capacity [6].

Foreigners are granted with a national regime to participate in the arbitration proceeding. Foreigners, on an equal footing with Russia, bear procedural obligations and enjoy procedural rights [7].

Article 41 of the Arbitration Procedural Code of the Russian Federation stipulates the rights of foreigners to familiarize themselves with the materials of the case, make extracts from them; make copies; state challenges; present evidence and get acquainted with the evidence submitted by other persons participating in the case prior to the commencement of the trial; participate in the study of evidence; ask questions to other participants in the arbitration proceeding, file petitions, make statements, give explanations to the arbitration case, give arguments on all issues arising during the consideration of the case; get acquainted with the petitions declared by other persons, object to the petitions and arguments of other persons participating in the case; to know about complaints filed by other persons participating in the case; be aware of the judicial acts adopted in this case and receive copies of judicial acts adopted in the form of a separate document, appeal against judicial acts; to enjoy other procedural rights granted to them by the Arbitration Procedural Code of the Russian Federation and other federal laws. In addition, they must conscientiously use their procedural rights. Abuse of procedural rights by persons participating in a case entails adverse consequences. Foreign persons participating in a case bear procedural obligations provided for by the Arbitration Procedural Code of the Russian Federation and other federal laws or entrusted to them by the arbitration court in accordance with the current legislation. Non-fulfillment of procedural obligations by foreign persons participating in the case entails certain sanctions. Procedural benefits are granted to foreign persons, if they are provided for by an international treaty of the Russian Federation.

The Federal Constitutional Law "On the Judicial System of the Russian Federation" establishes that proceedings in an arbitration court are conducted in Russian which is the state language of the Russian
Federation. The persons who participate in the case and do not speak Russian should be provided by the arbitration court with clarification and ensuring the right to get acquainted with the case materials, participate in court proceedings, to speak in court in their native language or freely chosen language of communication and use the services of an interpreter. Monetary amounts that are payable to interpreters and translators are related to legal costs. The Arbitration Procedural Code of the Russian Federation also provides that payment for the services of an interpreter or translator brought by the court to participate in the process, payment of daily allowances for him/her, as well as reimbursement of expenses incurred in connection with the appearance in the arbitration court, shall be made from the federal budget. According to Part 4, Article109 of The Arbitration Procedure Code of the Russian Federation the rule on the payment for the services of an interpreter or translator at the expense of the federal budget does not cover the reimbursement of expenses for the services of an interpreter or translator incurred by foreign persons and stateless persons, unless otherwise provided by an international treaty of the Russian Federation."The Convention on the Protection of Human Rights and Fundamental Freedoms" dated 04.11.1950 does not contain a provision on the right of participants in a civil dispute to use the free assistance of an interpreter or translator [8].

In accordance with the current legislation, court expenses are calculated and paid in the currency of the Russian Federation, including those levied from foreign participants [9].

When considering economic disputes between subjects of business activity that are residents of the countries members of the Commonwealth of Independent States (hereinafter referred to as the CIS), the state duty is paid in rubles of the Russian Federation with conversion at the rate of national currencies established by the national banks of the CIS countries. For these cases, the amount of state fee is determined by a separate Protocol [10].

Practice confirms the existence of three ways to pay the state fee by foreign participants in the course of arbitration proceeding. The fee may be paid from the accounts of foreign companies in credit institutions located on the territory of the Russian Federation. The state fee may be paid by an authorized representative of a foreign legal entity. If there are no bank accounts in the territory of the Russian Federation and the company does not have representatives in Russia, the arbitration court collects the amount of state fees by issuing a decision on that and sends it in the appropriate order to the foreign court in the appropriate order [11].

The equality of foreign participants in the arbitration proceeding with participants who are residents of our country and equality of their procedural rights is manifested in the same access to the national defense mechanism in court. However, the mechanism of judicial protection in different countries may differ. 
The national regime of the arbitration proceeding also presumes the distribution of provisions of the legislation of the Russian Federation on representation in relation to foreign entities. Representation of foreign entities has a number of features that affect the issues of registration of the representative's credentials and their confirmation, as well as the rules for determining the circle of persons entitled to act as representatives of foreign citizens and organizations.

The representatives can be advocates and other legal aid providers; the interests of foreigners can be protected and represented by a wider range of people, including foreign consuls and lawyers.

In the Russian Federation, the activities of foreign lawyers are allowed, although there are some restrictions. This follows from the content of the Federal Law "On Advocacy and Advocateship in the Russian Federation", which establishes that lawyers of foreign states conducting advocacy in the territory of the Russian Federation are registered in a special register. In addition, lawyers of foreign states can provide legal assistance in the territory of the Russian Federation on the issues of the law of a foreign state. At the same time, lawyers of foreign states are not allowed to provide legal assistance in the territory of the Russian Federation on issues related to the state secret of the Russian Federation.

One cannot fail to note the rights of foreign entities to represent and protect their interests by the consul of a foreign state that is located in the Russian Federation. Bilateral consular conventions between the Russian Federation and a number of foreign states, including Austria, Germany, Bulgaria, Vietnam, China, Poland, stipulate that the consul of the foreign state does not need a power of attorney in order to confirm its authority. [12]

One of the powers of foreign persons in exercising their rights in the arbitration proceeding is the opportunity to act not only as a complainant party or respondent party in a case, but also as a third person. If in the course of consideration of an economic dispute by an arbitration court the rights and legitimate interests of an alien are affected, it is obligatory to involve a foreign entity in the judicial process as a third person. This is confirmed by paragraph 9 of the Information Letter issued by the Presidium of the Supreme Arbitration Court of the Russian Federation No. 58 dated January 18, 2001 "Review of the practice of arbitration courts' resolution of disputes related to the protection of foreign investors".

\section{Conclusion}

Based on the results of the work, specific procedural features of examination of cases in an arbitration court in the Russian Federation involving a foreign element were revealed. A description was made of the procedure for considering these cases, the procedural rights and obligations of foreign persons.

In general, it can be noted that in the context of international agreements with the Russian Federation, the modern legal system of the Russian Federation and the world community constantly improve the order and specific features of arbitration cases involving foreign persons, and there is a noticeable liberalization of this process. However, we have to note that even greater work in this direction, improvement and simplification of the order of interaction with foreign courts considering economic disputes will only benefit the objective consideration of cases and the improvement of the administration of justice in arbitration courts. It is necessary to continue the initiated activities to develop and conclude international agreements, improve interaction and work of authorized state bodies. Greater and systematic implementation of modern technologies in the field of legal assistance will also have the necessary role in improving the litigation involving foreign elements. All these measures are possible only with the active interaction between judicial and executive bodies, as well as with the entire world community [12].

\section{Acknowledgements}

The work is carried out according to the Russian Government Program of Competitive Growth of Kazan Federal University.

\section{References}

1. Valeev D.K., Baranov S.Y. The reform of the civil procedural legislation: world trends // Life Science Journal. 2014. № 11(12s). P. 728-731

2. A. V. Argunov, M. R. Zagidullin, P. V. Krasheninnikov, V. V. Lisitsyn, V. M. Murshudova, R. B. Sitdikov. Commentary on the Civil Procedure Code of the Russian Federation (continued).Herald of the civil process. № 1. 2017. Pp. 97-144

3. Arbitration proceeding: Textbook for students of law schools and faculties / T. K. Andreeva, E. A. Borisova, S. A. Ivanova et al.; edited by M. K. Treushnikov. 3rd revised and enlarged edition.Moscow: Gorodets, 2007. 672 p. // ATP ConsultantPlus.

4. Valeev D.Kh. The influence of the ideas of Professor Gabriel Felixovich Shershenevich on modern legislation on insolvency (bankruptcy) in Russia // Studia Iuridica. vol. 57. 2013. P. 220-229 Arbitration Procedure Code of the Russian Federation dated 24.07.2002 N 95-FZ // SPS ConsultantPlus.

5. Valeev D.Kh., Sitdikov R.B., Novikov I.A. Civil procedure in the CIS: current state and prospect of development // Journal of Economics and Economic Education Research. Volume 17. Special Issue 2. 2016. P. 310-316.

6. Valeev D. Kh., Golubtzov V.G. Modernization of the Russian law: a review of the laws on enforcement proceedings // Life Science Journal. 2014. №11(8s). P. 234-238

7. Arbitration proceeding: a textbook / K. M. Arslanov, D. Kh. Valeev, R. N. Gimazov and others; responsible editor D. Kh. Valeev, M. Yu. Chelyshev. Moscow: Statute, 2010. 572 p. // ATP ConsultantPlus.

8. Convention for the Protection of Human Rights and Fundamental Freedoms.Rome, 04/11/1950. 
9. Maleshin D., Silvestri E., Sitgikov R., Valeev D. Reforming Russian Civil Procedure. Russian Law Journal. 2016; 4 (1): 142-147

10. The Agreement of the CIS countries dated 24 . 12. 1993 (edition of 10.12.2010) "On the amount of state duty and the procedure for its collection in the consideration of economic disputes between business entities of different states" // SPS ConsultantPlus.

11. Belyaeva N.G. Features of the consideration of cases involving foreign persons in the arbitration court: a practical guide. Moscow: Norma, Infra-M, 2012. 192 pp. // ATP ConsultantPlus

12. Arbitration proceeding: textbook / A. B. Absalyamov, I. G. Arsenov, E. A. Vinogradova and others; responsible editor V. V. Yarkov. 4 th edition, revised and enlarged.M.: Infotropic Media, 2010. 880 pp. // ATP ConsultantPlus.

13. Valeev D., Yu H, Krsljanin N., Kazan arbitration day: The rule-of-law development and regional governance // Russian Law Journal. - 2017. Vol. 5, Is. - P. 129-135. 